\title{
Medium and Large-sized Mammals of the Municipality of Pirajuí, São Paulo, Brazil
}

\author{
Rafael Martos-Martins ${ }^{1,2 *}$, Sarah Carolina Barbosa Cassa², Rafael Gustavo Capinzaiki \\ Ottonicar ${ }^{1,2}$, Isabella Brosens Barros ${ }^{2}$, Reginaldo José Donatelli² \\ ${ }^{1}$ Postgraduation Program, Bioscience Institute, São Paulo State University, UNESP, Botucatu, SP, Brazil. \\ ${ }^{2}$ Department of School of Sciences, São Paulo State University, Biological Sciences, UNESP, Botucatu, SP, Brazil. \\ *E-mail para correspondência: rafael.martos@yahoo.com.br
}

\section{RESUMO}

Mamíferos de médio e grande porte do município de Pirajuí, São Paulo, Brasil. Mamíferos desempenham um papel ecológico importante e estão relacionados a vários processos ecológicos. O objetivo do estudo foi listar espécies de mamíferos de médio e grande porte que ocorrem no município de Pirajuí, SP. O estudo foi realizado em área urbana, estradas que percorrem áreas rurais e em pequenos fragmentos de Mata Atlântica. Os dados foram obtidos durante um período de três anos por diferentes métodos: observação direta, registros de pegadas e por armadilhas fotográficas. Foram registradas 18 espécies de mamíferos de médio e grande porte pertencentes a 13 famílias e oito ordens, representando $40 \%$ das espécies de mamíferos de médio e grande porte que ocorrem no estado de São Paulo. Carnivora foi a ordem com o maior número de representantes, com sete espécies. Assim, o estudo fornece dados importantes sobre a ocorrência de certas espécies de mamíferos nesses ambientes frequentemente negligenciados, onde a falta de conhecimento pode levar a futuras extinções locais.

Palavras-chave: Biodiversidade, Conservação, Levantamento, Mastofauna, Região neotropical.

\section{ABSTRACT}

Mammals play an important ecological role and are related to several ecological processes. The objective of the study was to list medium and large-sized mammals species which occur in the municipality of Pirajuí, SP. The study was carried out in an urban area, roads that run through rural areas and in small fragments of Atlantic Forest. The data were obtained during a period of three years by different methods: direct observation, footprints records and by camera traps. We recorded 18 medium and large-sized mammals species belonging to 13 families and eight orders, representing $40 \%$ of medium and large-sized mammals species that occur in the State of São Paulo. Carnivora was the order with the highest number of representatives, with seven species. Thereby, the study provides important data about the occurrence of certain species of mammals in these often-neglected environments, where the lack of knowledge may lead to a future local extinctions.

Keywords: Biodiversity, Conservation, Mastofauna, Neotropical region, Survey. 


\section{INTRODUCTION}

Brazil has the greatest mammal richness in the Neotropical region, with 732 mammal species distributed in 12 Orders and 50 families (Paglia et al., 2012; MMA, 2016). In the state of São Paulo, 231 taxa were registered of which 45 account for medium and large-sized mammals (Vivo et al., 2011).

Due to a historical agricultural and urban expansion, current mammals have taken refuge in small forest remnants, which are common in the State of São Paulo, but their composition is poorly studied (Briani et al., 2001). They play an important role in the environment and are associated with several ecological processes such as: forest regeneration, prey control, seed dispersal, pollination, herbivory, among others (Abreu-Jr \& Köhler, 2009).

The greatest threats to terrestrial mammals in Brazil come from the loss and fragmentation of their habitat resulting from human activities and strong hunting pressure (Costa et al., 2005). In the Atlantic Forest area, one of the world's biodiversity hotspots (Myers et al., 2000), mammals are the group with the highest proportion of endangered species, with approximately $25 \%$ of the species included in the Red List of Endangered Brazilian Fauna (ICMBio, 2018). Seasonal Semideciduous Forest are one of the most fragmented ecosystems in the Atlantic Forest with few protected areas and less than $10 \%$ of the remaining vegetation (Ribeiro et al., 2009).

Studies concerning the consequences of forest fragmentation and biodiversity conservation have increased substantially because a significant part of this biodiversity is located in small forest fragments, which are poorly studied and historically forgotten by conservation initiatives (Viana \& Pinheiro, 1998; Santos et al., 2013). For the development of conservation actions, basic knowledge of the species as well as its spatial distribution is indispensable, including inventories of mammals (Kasper et al., 2007).

Aiming to contribute with data on the occurrence and distribution of mammals in the region, the objective of this study was to inventory medium and large-sized mammals in an area under anthropogenic influence such as rural areas and small forest fragments associated with them in the municipality of Pirajuí, state of São Paulo, Brazil. 


\section{MATERIAL AND METHODS}

\section{Study Area}

The municipality of Pirajuí is located in the northwest region of the State of São Paulo, Brazil $\left(21^{\circ} 59^{\prime} 56^{\prime \prime} \mathrm{S} ; 49^{\circ} 27^{\prime} 25^{\prime \prime} \mathrm{W}\right)$. The municipality has an area of $823,350 \mathrm{~km}^{2}$, covering a transition area of Atlantic Forest and Cerrado (Savannah) biomes (IBGE, 2000). This study was carried out in the urban area, on unpaved roads that cross rural areas and in small fragments of seasonal semideciduous forest (Figure 1). The forest fragments, which are the main ones with free access, are isolated within matrix of cultivated areas, mainly sugarcane, orange and eucalyptus plantations and pasture areas for cattle.

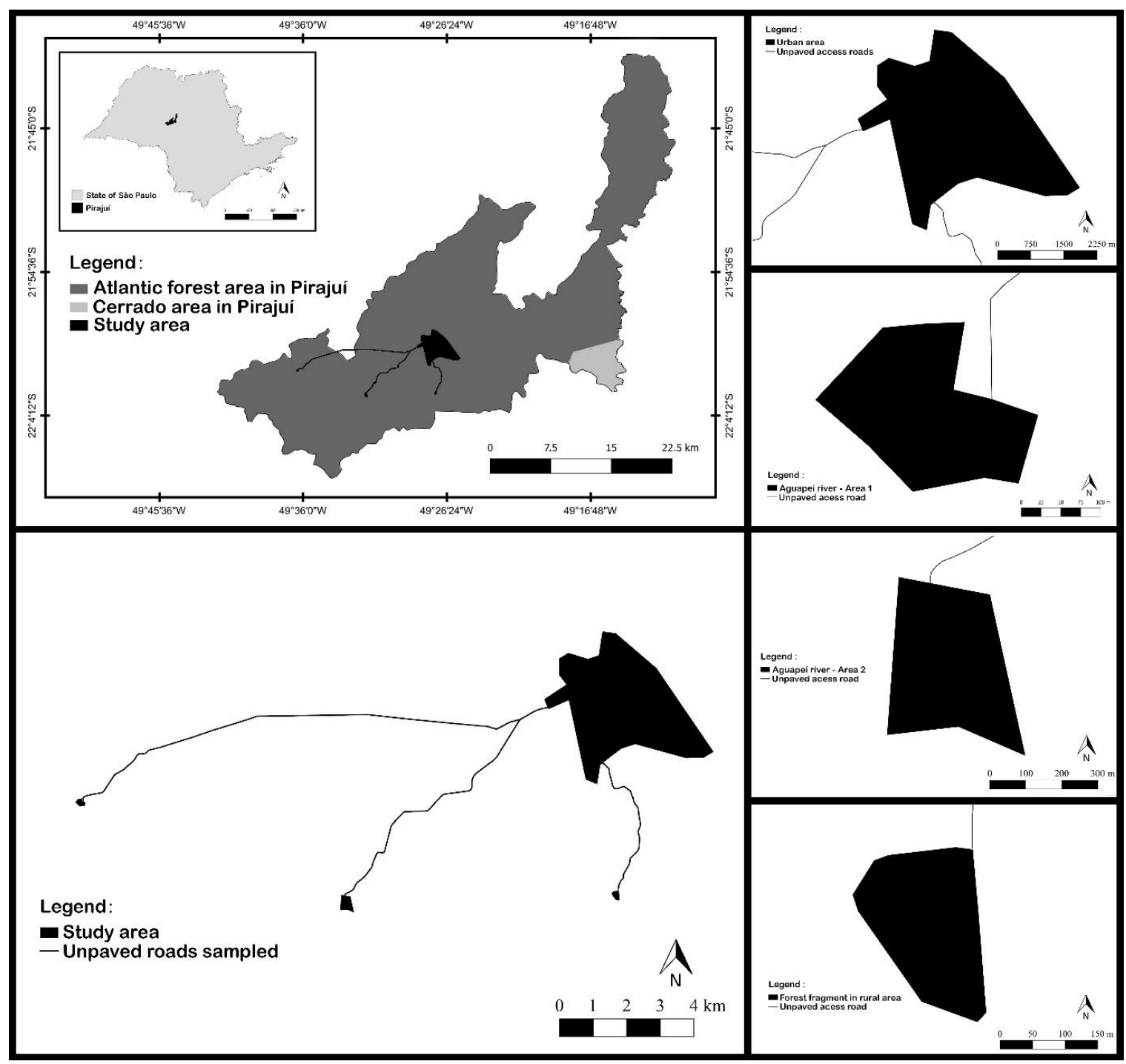

Figure 1. Map of the municipality of Pirajuí, in the interior of the state of São Paulo, Brazil, highlighting the studied area. 


\section{Sampling}

Data from this study were obtained over a three-year period, from April 2014 to March 2017, when the mammalian species were recorded through different methods: direct observation, footprint records and records from camera traps (Covert 'The Deuce' Trail Camera). At least 5 hours of monthly inventory was taken in the area, with an average of $1 \mathrm{~h} 30 \mathrm{~min}$ in each fragment and 30 minutes in the urban area, with a total of 180 hours sampling effort. Domestic mammals found in the study area were not considered. The species nomenclature followed Paglia et al. (2012).

\section{Analysis}

By means of the survey of medium and large-sized mammals, a list of species for the municipality of Pirajuí was elaborated and, in addition, the registered species were classified into trophic guilds based on their diets. Dietary information on each species was based on Paglia et al. (2012) and on field observations.

\section{RESULTS}

A total of 18 species of medium and large-sized mammals, belonging to 13 families and eight orders, were registered. This richness represents $40 \%$ of the total medium and large-sized mammal species in the State of São Paulo (Table 1).

The Order Carnivora showed the highest number of records with seven species $(38,88 \%)$. We recorded two species (11,11\%, each Order) for Cingulata, Lagomorpha, Primates and Rodentia. We recorded one species (5,55\%) for Didelphimorphia, Pilosa and Artiodactyla.

Among the cataloged species, 13 were registered using the methodology of direct observation. Using the footprint records methodology, eight species were recorded and seven species were recorded using cameras traps.

In relation to the food categories, five species $(27,77 \%)$ were classified as frugivore/omnivore, three species $(16,66 \%)$ were classified as insectivore/omnivore and three as herbivore grazer, two species $(11,11 \%)$ as carnivore and there was only one record $(5,55 \%)$ for the guilds myrmecophage, piscivore, folivore/frugivore, frugivore/herbivore and frugivore/granivore. 
Table 1. List of medium and large-sized mammals species of municipality of Pirajuí, State of São Paulo, Brazil. Trophic guild: $\mathrm{Fr}=$ Frugivore; $\mathrm{On}=$ Omnivore; $\mathrm{In}=$ Insectivore; $\mathrm{Myr}=$ Myrmecophage; $\mathrm{Fo}=$ Folivore; $\mathrm{Hb}=$ Herbivore grazer; $\mathrm{Ca}=$ Carnivore; $\mathrm{Os}=$ Piscivore e $\mathrm{Gr}=$ Granivore. Registration method: $\mathrm{DO}=$ direct observation; $\mathrm{F}=$ footprint records e CAM = records from camera traps.

\begin{tabular}{|c|c|c|c|c|}
\hline Order / Family & Taxa & Common name & $\begin{array}{l}\text { Trophic } \\
\text { guild }\end{array}$ & $\begin{array}{l}\text { Registration } \\
\text { method }\end{array}$ \\
\hline $\begin{array}{l}\text { Didelphimorphia } \\
\text { Didelphidae }\end{array}$ & Didelphis albiventris Lund, 1840 & $\begin{array}{l}\text { White-eared } \\
\text { Opossum }\end{array}$ & Fr/On & DO/CAM \\
\hline \multirow[t]{2}{*}{$\begin{array}{l}\text { Cingulata } \\
\text { Dasypodidae }\end{array}$} & Dasypus novemcinctus Linnaeus, 175 & $\begin{array}{l}\text { Nine-banded } \\
\text { Armadillo }\end{array}$ & In/On & DO/CAM \\
\hline & Euphractus sexcinctus (Linnaeus, 1758) & $\begin{array}{l}\text { Six-Banded } \\
\text { Armadillo }\end{array}$ & In/On & CAM \\
\hline $\begin{array}{l}\text { Pilosa } \\
\text { Myrmecophagidae }\end{array}$ & Tamandua tetradactyla (Linnaeus, 1758) & $\begin{array}{l}\text { Southern } \\
\text { Tamandua }\end{array}$ & Myr & CAM \\
\hline $\begin{array}{l}\text { Primates } \\
\text { Cebidae }\end{array}$ & Sapajus nigritus Goldfuss, 1809 & $\begin{array}{l}\text { Black-capped } \\
\text { Capuchin }\end{array}$ & $\mathrm{Fr} / \mathrm{On}$ & $\mathrm{DO} / \mathrm{F}$ \\
\hline $\begin{array}{l}\text { Primates } \\
\text { Atelidae }\end{array}$ & Alouatta guariba (Humboldt, 1812) & $\begin{array}{l}\text { Brown Howler } \\
\text { Monkey }\end{array}$ & Fo/Fr & DO \\
\hline \multirow{2}{*}{$\begin{array}{l}\text { Lagomorpha } \\
\text { Leporidae }\end{array}$} & Sylvilagus brasiliensis (Linnaeus, 1758) & Forest Rabbit & $\mathrm{Hb}$ & DO \\
\hline & Lepus europaeus Pallas, 1778 & European Hare & $\mathrm{Hb}$ & DO \\
\hline \multirow{2}{*}{$\begin{array}{l}\text { Carnivora } \\
\quad \text { Felidae }\end{array}$} & Puma concolor (Linnaeus, 1771) & Puma & $\mathrm{Ca}$ & $\mathrm{F}$ \\
\hline & Leopardus pardalis (Linnaeus, 1758) & Ocelot & $\mathrm{Ca}$ & F/CAM \\
\hline $\begin{array}{l}\text { Carnivora } \\
\quad \text { Canidae }\end{array}$ & Cerdocyon thous (Linnaeus, 1766) & Crab-eating Fox & In/On & $\mathrm{DO} / \mathrm{F}$ \\
\hline \multirow{2}{*}{$\begin{array}{l}\text { Carnivora } \\
\quad \text { Mustelidae }\end{array}$} & Eira barbara (Linnaeus, 1758) & Greyheaded Tayra & $\mathrm{Fr} / \mathrm{On}$ & DO/CAM \\
\hline & Lontra longicaudis (Olfers, 1818) & Neotropical Otter & Ps & DO \\
\hline \multirow[t]{2}{*}{$\begin{array}{l}\text { Carnivora } \\
\quad \text { Procyonidae }\end{array}$} & Nasua nasua (Linnaeus, 1766) & $\begin{array}{l}\text { South American } \\
\text { Coati }\end{array}$ & Fr/On & DO \\
\hline & $\begin{array}{l}\text { Procyon cancrivorus (G.[Baron] Cuvier, } \\
\text { 1798) }\end{array}$ & $\begin{array}{l}\text { Crab-eating Rac- } \\
\text { coon }\end{array}$ & $\mathrm{Fr} / \mathrm{On}$ & $\mathrm{F}$ \\
\hline $\begin{array}{l}\text { Artiodactyla } \\
\text { Cervidae }\end{array}$ & $\begin{array}{l}\text { Mazama gouazoubira (G. Fischer [von } \\
\text { Waldheim], 1814) }\end{array}$ & Brown Brocket & $\mathrm{Fr} / \mathrm{Hb}$ & DO \\
\hline $\begin{array}{l}\text { Rodentia } \\
\text { Caviidae }\end{array}$ & $\begin{array}{l}\text { Hydrochoerus hydrochaeris (Linnaeus, } \\
1766 \text { ) }\end{array}$ & Capybara & $\mathrm{Hb}$ & $\mathrm{DO} / \mathrm{F}$ \\
\hline $\begin{array}{l}\text { Rodentia } \\
\text { Dasyproctidae }\end{array}$ & Dasyprocta azarae Lichtenstein, 1823 & Azara's Agouti & $\mathrm{Fr} / \mathrm{Gr}$ & DO/F/CAM \\
\hline
\end{tabular}




\section{DISCUSSION}

We highlight the conservation importance of the studied region in Pirajuí where we recorded species with great ecological importance, such as individuals of the Order Carnivora. Due to its great mobility and ability to explore anthropic environments, species of Carnivora Order often occur in fragmented landscapes (Lyra-Jorge et al., 2008), such as the area where the study was carried out.

Carnivores are crucial for balancing ecosystems as they maintain and restore the diversity and resilience of the environment through prey control and seed dispersal processes (Terborgh, 1992), and the animals of this order usually rely on forested areas and have a low population density (Robinson \& Redford, 1986). In addition, the high proportion of species in this order seems to be common in surveys conducted in areas of Atlantic forest and Cerrado biomes (Chiarello, 1999; Santos-Filho \& Ferreira da Silva, 2002; Negrão \& Valladares-Pádua, 2006; Modesto et al., 2008; Prado et al., 2008; Eduardo \& Passamani, 2009; Pessôa et al., 2009; Bocchiglieri et al., 2010; Bruna et al., 2010; Penido \& Zanzini, 2012).

Despite the absence of records during the study period, it was expected the occurrence of some species that have been recorded in inventories carried out in municipalities close to our study area: Gália, SP and Alvinlândia, SP (Tabanez et al., 2005); Anhembi, SP (Antunes \& Eston, 2009); Botucatu, SP (Alves et al., 2012); São Carlos, SP (Dias et al., 2012) and Jaú, SP (Reale et al., 2014). These species are those of the genus Cabassous sp. (Tabanez et al., 2005; Antunes \& Eston, 2009; Alves et al., 2012; Reale et al., 2014); Chrysocyon brachyurus (Illiger, 1815) (Dias et al., 2012; Reale et al., 2014); Conepatus sp. (Alves et al., 2012; Dias et al., 2012); Didelphis aurita (Wied-Neuwied, 1826) (Tabanez et al., 2005); Galictis cuja (Molina, 1782) (Antunes \& Eston, 2009); Galictis vittata (Schreber, 1776) (Tabanez et al., 2005; Dias et al., 2012); Mazama americana (Erxleben, 1777) (Tabanez et al., 2005; Antunes \& Eston, 2009); Myrmecophaga tridactyla Linnaeus, 1758 (Alves et al., 2012); Coendou spinosus (F. Cuvier, 1823) (Dias et al., 2012) and Coendou villosus (F. Cuvier, 1823) (Tabanez et al., 2005; Antunes \& Eston, 2009; Reale et al., 2014). The absence of these species can be attributed to a local low population density. It is also possible that the methodology used in the study was not suitable for the registration of these species or a local extinction.

Moreover, in the studies mentioned above, carried out in nearby localities, the researchers found, in addition to the species registered in Pirajuí, others that present greater sensitivity to environmental changes, such as: Brachyteles arachnoides (É. Geoffroy, 1806) (Antunes \& Eston, 2009); Callicebus sp. (Dias et al., 2012); Callicebus nigrifrons (Spix, 1823) (Antunes \& Eston, 2009); Cuniculus paca (Linnaeus, 1766) 
(Tabanez et al., 2005; Antunes \& Eston, 2009; Alves et al., 2012; Reale et al., 2014); Lycalopex vetulus (Lund, 1842) (Reale et al., 2014); Pecari tajacu (Linnaeus, 1758) (Tabanez et al., 2005; Antunes \& Eston, 2009); Puma yagouaroundi (É. Geoffroy, 1803) (Tabanez et al., 2005; Antunes \& Eston, 2009; Reale et al., 2014); Tapirus terrestris (Linnaeus, 1758) (Tabanez et al., 2005) and Tayassu pecari (Link, 1795) (Tabanez et al., 2005; Antunes \& Eston, 2009). These species need larger forest areas and, within these areas, they need to find specific resources such as food and/or habitat resources. Unlike the small fragments sampled in Pirajuí, who suffered a greater degree of anthropic degradation, the sample areas of the studies that recorded the presence of these species are larger and probably provide the conditions for these species to maintain viable populations.

In relation to registered species, we highlight those with conservation concerns, being in the State of São Paulo Leopardus pardalis and Puma concolor are categorized as threatened; Sapajus nigritus and Lontra longicaudis as nearly-threatened (São Paulo - Decreto 60.133, 2014). At national level, Puma concolor and Alouatta guariba are considered vulnerable (VU) (ICMBio, 2018) and at global level, IUCN (2018) classifies Sapajus nigritus and Lontra longicaudis on its Red List as nearly-threatened species (NT).

Among the registered species, the puma (Puma concolor) is found throughout the entire national territory and has suffered with deforestation, habitat fragmentation, hunting, retaliation due to domestic animal predation, forest fires and roadkill, which can cause a future decline on the national subpopulation (Azevedo et al., 2013). The conservation of large felines such as the puma requires extensive areas, once these animals need large life territories and many environmental resources.

The Brown Howler Monkey (Alouatta guariba) is endemic to the Atlantic Forest and may live in primary or secondary forests, as well as highly man-disturbed habitats, since they have an eclectic diet adaptable to environmental conditions (Reis et al., 2011). Nonetheless, habitat loss, hunting and capturing are the main reasons why this species is framed as vulnerable. In addition, individuals have been dying due to cases of Yellow Fever in some regions of Brazil, as in the State of São Paulo (Bicca-Marques et al., 2018). The species is host and very susceptible to the virus, which is transmitted by mosquitoes of the genera Haemagogus and Sabethes in the wild environment and Aedes aegypti in the urban environment (Monath \& Vasconcelos, 2015; Silva et al., 2019; Ministério da Saúde, 2019).

Knowing the species that occur in a certain area is an important tool because without this information it is practically impossible to develop any conservation initiatives (Cullen-Jr et al., 2003). Therefore, studies carried out in environments similar to the studied area become important, since these sites can present a high species richness, which reinforces the need to develop conservation measures for these forest remnants. 


\section{CONCLUSION}

This study showed the importance of wildlife inventories performed in areas under anthropic influence, such as rural sites and small fragments associated with them, providing important data about the occurrence of certain species in these often-neglected environments, where the lack of knowledge may lead to a future local extinction. This study contributes to acknowledging the wildlife potential in the region and the need for conservation measures in the studied area.

\section{REFERENCES}

Abreu Júnior, E.F. \& Köhler, A. 2009. Mastofauna de médio e grande porte na RPPN da UNISC, RS, Brasil. Biota Neotropica 9(4): 169-174.

Alves, T.R.; Fonseca, R.C. \& Engel, V.L. 2012. Mamíferos de médio e grande porte e sua relação com o mosaico de habitats na cuesta de Botucatu, Estado de São Paulo, Brasil. Iheringia: Série Zoologia 102(2): 150-158.

Antunes, A.Z. \& de Eston, M.R. 2009. Mamíferos (Chordata: Mammalia) florestais de médio e grande porte registrados em Barreiro Rico, Anhembi, Estado de São Paulo. Mammals (Chordata: Mammalia) recorded in Barreiro Rico, State of São Paulo, Southeastern Brazil. Revista do Instituto Florestal 21(2): 201-215.

Azevedo, F.C.; Lemos, F.G.; de Almeida, L.B.; de Campos, C.B.; de Mello Beisiegel, B.; de Paula, R.C.; Crawshaw, P.G.; de Barros Ferraz, K.M.P. \& de Oliveira, T.G. 2013. Avaliação do risco de extinção da onça-parda Puma concolor (Linnaeus, 1771) no Brasil. Biodiversidade Brasileira 1: 107-121.

Bicca-Marques, J.C.; Alves, S.L.; Ingberman, B.; Buss, G.; Fries, B.G.; Alonso, A.C.; Da Cunha, R.G.T. \& Miranda, J.M.D. 2018. Alouatta guariba clamitans Cabrera, 1940, pp.155-161. In: Instituto Chico Mendes de Conservação da Biodiversidade (org.). Livro Vermelho da Fauna Brasileira Ameaçada de Extinção: Volume II - Mamíferos. Brasília, DF, ICMBio. 492p.

Bocchiglieri, A.; Mendonça, A.F. \& Henriques, R.P.B. 2010. Composição e diversidade de mamíferos de médio e grande porte no Cerrado do Brazil central. Biota Neotropica 10(3): 169-176.

Briani, D.C.; Santori, R.T.; Vieira, M.V. \& Gobbi, N. 2001. Mamíferos não voadores de um fragmento de mata mesófila semidecídua, do interior do Estado de São Paulo, Brasil. Holos Environment 1(2): 141-149. 
Bruna, E.M.; Guimarães, J.F.; Lopes, C.T.; Duarte, P.; Gomes, A.C.L.; Belentani, S.C.S.; Pacheco, R.; Facure, K.G.; Lemos, F.G. \& Vasconcelos, H.L. 2010. Mammalia, Estação Ecológica do Panga, a Cerrado protected area in Minas Gerais state, Brazil. Check List 6(4): 668-675.

Cepagri. 2017. Clima dos Municípios Paulistas. Available at: https://www.cpa.unicamp.br/outras-informacoes/clima_muni_438.html. Accessed on: 10/03/2017.

Chiarello, A.G. 1999. Effects of fragmentation of the Atlantic forest on mammals communities in southeastern Brazil. Biological Conservation 89(1): 71-82.

Costa, L.P.; Leite, Y.R.L.; Mendes, S.L. \& Ditchfield, A.D. 2005. Conservação de mamíferos no Brasil. Megadiversidade 1(1): 103-112.

Cullen, J.R.; L.; Rudran, R. \& Valladares-Padua, C. 2003. Métodos de Estudos em Biologia da Conservação e Manejo da Vida Silvestre. Curitiba, Editora UFPR. 665p.

Dias, W.A.F.; Tezori, R.F.F. \& Oliveira, A.K. 2012. Registro de mamíferos de médio e grande porte em dois fragmentos florestais no município de São Carlos, Estado de São Paulo. Multiciência 11: 277-293.

Eduardo, A.A. \& Passamani, M. 2009. Mammals of medium and large size in Santa rita do Sapucaí, Minas Gerais, southeastern Brazil. Check List 5(3): 399-404.

IBGE. 2000. Municipios Brasileiros. Available at: http://www.cidades.ibge.gov.br. Acessed on: $10 / 03 / 2017$.

ICMBio - Instituto Chico Mendes de Conservação da Biodiversidade. 2018. Livro Vermelho da Fauna Brasileira Ameaçada de Extinção: Volume II - Mamíferos. Brasília, DF, ICMBio. 492p.

IUCN. 2017. The IUCN Red List of Threatened Species. Available at: https://www.iucnredlist.org. Accessed on: $28 / 01 / 2017$.

Kasper, C.B.; Feldens, M.J.; Mazin, F.D.; Schneider, A.; Cademartori, C.V. \& Grillo, H.C.Z. 2007. Mamíferos do Vale do Taquari, Região Central do Rio Grande do Sul. Biociências 15(1): 53-62.

Lyra-Jorge, M.C.; Ciocheti, G. \& Pivello, V.R. 2008. Carnivores mammals in a fragmented landscape in northeast of São Paulo state, Brazil. Biodiversity and Conservation 17: 1573-1580.

Ministério da Saúde. 2019. Febre amarela: sintomas, tratamento, diagnóstico e prevenção. Available at: http://saude.gov.br/saude-de-a-z/febre-amarela-sintomas-transmissao-e-prevencao. Acessed on: 28/09/2019. 
MMA - Ministério do Meio Ambiente. 2016. Sumário Executivo do Livro Vermelho da Fauna Brasileira Ameaçada de Extinção. Brasília, DF, (ICMBio). 75p.

Modesto, C.T.; Pessôa, F.S; Jordão-Nogueira, T.; Enrici, M.C.; Costa, L.M.; Attias, N.; Almeida, J.; Raíces, D.S.L.; Albuquerque, H.G.; Pereira, B.C.; Esbérard, C.E.L. \& Bergallo, H.G. 2008. Mammals, Serra da Concórdia, state of Rio de Janeiro, Brazil. Check List 4(3): 341-348.

Monath, T.P.; Vasconcelos, P.F.C. 2015. Yellow fever. Journal of Clinical Virology 64: 160-173

Myers, N.; Mittermeier, R.A.; Mittermeier, C.G.; Fonseca, G.A.B. \& Kent, J. 2000. Biodiversity hotspots for conservation priorities. Nature 403: 853-858.

Negrão, M.F.F. \& Valladares-Pádua, C. 2006. Registros de mamíferos de maior porte na Reserva Florestal do Morro Grande, São Paulo. Biota Neotropica 6(2): 1-13.

Paglia, A.P.; Fonseca, G.A.B.; Rylands, A.B.; Herrmann, G.; Aguiar, L.M.S.; Chiarello, A.G.; Leite, Y.L.R.; Costa, L.P.; Siciliano, S.; Kierulff, M.C.M.; Mendes, S.L.; Tavares, V.C.; Mittermeier, R.A. \& Patton, J.L. 2012. Lista Anotada dos Mamíferos do Brasil 2a Edição/Annotated Checklist of Brazilian Mammals. Occasional Papers in Conservation Biology 6: 1-82.

Penido, G. \& da Silva Zanzini, A.C. 2012. Checklist of large and medium-sized mammals of the Estação Ecológica Mata do Cedro, an Atlantic forest remnant of central Minas Gerais, Brazil. Check List 8(4): 712 717.

Pessôa, F.S.; Modesto, T.C.; Albuquerque, H.G.; Attias, N. \& Bergallo, H. 2009. Non-volant mammals, Reserva Particular do Patrimônio Natural (RPPN) Rio das Pedras, municipality of Mangaratiba, state of Rio de Janeiro, Brazil. Check List 5(3): 577-586.

Prado, M.R.; Rocha, E.C. \& Lessa, G.M. 2008. Mamíferos de médio e grande porte em um fragmento de Mata Atlântica, Minas Gerais, Brasil. Revista Árvore 32(4): 741-749.

Reale, R.; Fonseca, R.C.B. \& Uieda, W. 2014. Medium and large-sized mammals in a private reserve of natural heritage in the municipality of Jaú, São Paulo, Brazil. Check List 10(5): 997-1004

Reis, N.R.; Peracchi, A.L.; Pedro, W.A. \& Lima, I.P. 2011. Mamíferos do Brasil. 2 ed. Londrina, Nelio R. dos Reis. 439p.

Ribeiro, M.C.; Metzger, J.P.; Martensen, A.C.; Ponzoni, F.J. \& Hirota, M.M. 2009. The Brazilian Atlantic Forest: how much is left, and how is the remaining forest distributed? Implications for conservation. Biological Conservation 142(6): 1141-1153. 
Robinson, J.G. \& Redford, K.H. 1986. Body size, diet, and population density of Neotropical forest mammals. The American Naturalist 128(5): 665-680.

Santos, C.F.; Bueno, B. \& Casella, J. 2013. Comparação entre métodos de amostragem e eficiência de iscas na atração de mamíferos de médio e grande porte no Cerrado. Neotropical Biology \& Conservation 8(3): 156-164.

Santos-Filho, M. \& Silva, M.N.F. 2002. Uso de habitats por mamíferos em área de Cerrado do Brasil Central: um estudo com armadilhas fotográficas. Zoociências 4(1): 57-73.

SÃO PAULO - DECRETO 60.133/2014. 2014. Declara as espécies da fauna silvestre ameaçadas de extinção, as quase ameaçadas e as deficientes de dados para avaliação no Estado de São Paulo e dá providências correlatas. Diário Oficial Poder Executivo - Seção I, São Paulo, 124 (27) - 25. Available at: http://www.al.sp.gov.br/repositorio/legislacao/decreto/2014/decreto-60133 07.02.2014.html. Accessed on: $28 / 01 / 2017$.

Silva, E.F.; Oliveira, F.; Correa, L.F.; Oliveira, M.N.; Coutinho, P.S. \& Gonçalves, S.J.C. 2019. Ações voltadas a cobertura vacinal contra Febre Amarela a partir de atividades prática de epidemiologia. Revista PróUniverSUS 10(1): 110-118.

Tabanez, M.F.; Durigan, G.; Keuroghlian, A.; Barbosa, A.F.; Freitas, C.A.; Silva, C.E.F.; Silva, D.A. da; Eaton, D.P.; Brisolla, G.; de Faria, H.H.; Mattos, I.F.A.; Lobo, M.T.; Barbosa, M.R.; Rossi, M.; Souza, M.G.; Machado, R.B.; Pfeifer, R.M.; Ramos, V.S.; Andrade, W.J. \& Contieri, W.A. 2005. Plano de manejo da Estação Ecológica dos Caetetus. Instituto Florestal Série Registros 29: 1-104.

Terborgh, J. 1992. Maintenance of diversity in tropical forests. Biotropica 24(2b): 283-292.

Viana, V.M. \& Pinheiro, L.A.F.V. 1998. Conservação da biodiversidade em fragmentos florestais. Série técnica IPEF 12(32): 25-42.

Vivo M.; Carmignotto, A.P.; Gregorin, R.; Hingst-Zaher, E.; lack-Ximenes, G.E.; Miretzki, M.; Reis PercequiIlo, A.; Rollo Junior, M.M.; Rossi, R.V. \& Taddei, V.A. 2011. Checklist dos mamíferos do Estado de São Paulo, Brasil. Biota Neotropica 11(1a): 1-21. 